\title{
Granger causality of the socioeconomic development indicator on fiscal management of Brazilian municipalities
}

\author{
João Paulo de Oliveira Louzano' \\ Luiz Antonio Abrantes² \\ Marco Aurélio Marques Ferreira² \\ Robson Zuccolotto ${ }^{3}$ \\ 1 Universidade Federal dos Vales do Jequitinhonha e Mucuri, Teófilo Otoni / MG — Brazil \\ 2 Universidade Federal de Viçosa / Programa de Pós-Graduação em Administração, Viçosa / MG — Brazil \\ ${ }^{3}$ Universidade Federal do Espirito Santo / Programa de Pós-Graduação em Ciências Contábeis, Vitória / ES — Brazil
}

\begin{abstract}
The relationship between fiscal management and development has been the subject of many applied studies, but there are still incipient studies investigating the causal relationship between them. Based on the hypothesis that efficiency in fiscal management would result in better municipal socioeconomic indicators, the objective of this work was to investigate the relationship between fiscal management and development in 4,317 Brazilian municipalities in the period from 2006 to 2013 The regression model was used with panel data and Granger's causality application. The results indicated that there is no causal relationship between fiscal management and development, It was also verified the causal relationship of development to fiscal management, demonstrating that efficient fiscal management does not always signal the efficient use of public resources to promote development.
\end{abstract}

Keywords: fiscal management; development; causality.

\section{Causalidade de Granger do índice de desenvolvimento socioeconômico na gestão fiscal dos municípios brasileiros}

A relação entre gestão fiscal e desenvolvimento tem sido objeto de muitos estudos aplicados, mas ainda são incipientes os trabalhos que investigam a relação de causalidade entre eles. Partindo da hipótese de que a eficiência na gestão fiscal resultaria em melhores indicadores socioeconômicos municipais, o objetivo desta pesquisa consistiu em investigar a relação entre gestão fiscal e desenvolvimento em 4.317 municípios brasileiros, no período de 2006 a 2013. Adotou-se o modelo de regressão com dados em painel e aplicação de causalidade de Granger. Os resultados indicaram a inexistência de relação de causalidade entre gestão fiscal e desenvolvimento e confirmou a relação de causalidade do desenvolvimento para a gestão fiscal, demonstrando que nem sempre a gestão fiscal eficiente sinaliza o uso eficiente dos recursos públicos para promover o desenvolvimento.

Palavras-chave: gestão fiscal; desenvolvimento; causalidade.

\section{Causalidad de Granger del índice de desarrollo socioeconómico en la gestión fiscal de los municipios brasileños}

La relación entre la gestión fiscal y el desarrollo ha sido objeto de muchos estudios aplicados, pero todavía son incipientes estudios que investigan la relación causal entre ellos. Partiendo de la hipótesis de que la eficiencia en la gestión fiscal resultaría en los mejores indicadores socioeconómicos municipales, el objetivo de este estudio fue investigar la relación entre la gestión fiscal y el desarrollo en 4.317 municipios brasileños de 2006 a 2013. Se adoptó el modelo de regresión con datos de panel y la aplicación de causalidad de Granger. Los resultados indicaron que no existe una relación causal entre la administración fiscal y el desarrollo y confirmó la relación de causalidad del desarrollo para la gestión fiscal, lo que demuestra que la administración fiscal no siempre eficiente señala el uso eficiente de los recursos públicos para promover el desarrollo.

Palabras Clave: gestión tributaria; desarrollo; causalidad. 


\section{INTRODUCTION}

Resource scarcity drives the state to balance revenue and expenditure, create institutions and economic conditions conducive for efficient and effective socioeconomic policies related to education, health, employment and income. National and international literature relatively asserts that economic development is only possible when the state practice effective, transparent, responsive and accountable management (Bresser-Pereira, 2008; Costa, Ferreira, Braga, \& Abrantes, 2015; Kwak, 2017).

Public administration in Brazil has been permeated by public account imbalances for a long time. The quest to maintain fiscal balance and financial management generated Law n. 9,496 (1997) and Complementary Law n. 101 (LC 101, 2000). Law n. 9,496 (1997) consists of a program to control state and municipality debts, while complementary Law n. 101 (LC 101, 2000) establishes public finance standards for responsible fiscal management. It is important to emphasize the importance of establishing fiscal management characterized by efficient allocation of financial resources coupled with economic rationality of the government.

The relationship between fiscal management and socioeconomic development has been the subject of many applied studies (Easterly \& Rebelo, 1993; G. A. L Fialho \& T. M. M Fialho, 2015a; Jorge \& Cajazeira, 2015; Kneller, Bleaney, \& Gemmell, 1999; Scarpin \& Slomski, 2007), yet causal studies on the relationship between fiscal management and socioeconomic indicators in subnational units are still incipient. Furthermore, there is no consensus on the existence and direction of causality between these two variables.

With regard to fiscal policy, the changes promoted by the Constitution of the Federative Republic of Brazil ([CF], 1988) generated new agreements and socio-political responsibilities, along with political and financial decentralization of federal entities, most importantly tax decentralization of the state and municipalities. Despite the consequent increase in fiscal capacity, socioeconomic development has been heterogeneous, given the main criteria for the transfer of revenues contemplates population size and economic potential of the entities, especially for municipalities.

From this perspective, does good municipal fiscal management imply better socioeconomic indicators? Or better still, is there a causal relationship between fiscal management and socioeconomic development? It is hypothesized that efficiency in fiscal management implies better municipal socioeconomic indicators, resulting in a positive economic causality relationship between fiscal management and municipal development. This hypothesis is investigated through the analysis of the causal relationship between fiscal management - measured by the Firjan Index of Fiscal Management (IFGF) (Federation of Industries of the State of Rio de Janeiro [Firjan], 2015b) - and municipal development of Brazilian municipalities - measured by the Firjan Municipal Development Index (IFDM) (Firjan, 2015a). In this sense, the objective of this research was to investigate the relationship between fiscal management and development, based on 4,317 Brazilian municipalities and the period, 2006 to 2013.

The study is justified because the public financial sector lacks data on the casual relationship between the level of fiscal management and socioeconomic indicators, especially after the new legal framework governing the budget balance of subentities. In addition, the study offers a practical contribution as regards providing evidence for discussions on the reformulation of the distribution of resources among federal entities, the central axis in fiscal federalism. 


\section{FISCAL MANAGEMENT AND SOCIOECONOMIC DEVELOPMENT}

The State uses several instruments to guarantee socioeconomic development and distribution of income. Among these state controlled instruments, progressive tax system and tax exemptions are highlighted (Massardi \& Abrantes, 2016).

Socioeconomic development does not entail only industrialization, employment and income growth, but also other determinants such as health and education services (Sen, Motta, \& Mendes, 2000). In this sense, the IFDM index, developed by the Economic Studies Management at Firjan (2015a) monitors the development (employment and income, education and health) of more than 5 thousand Brazilian municipalities. It is elaborated exclusively based on official statistics of the Ministry of Labor, Ministry of Education (MEC) and Ministry of Health (MH). The index ranges from 0 (minimum) to 1 (maximum) and classifies municipalities into 4 categories of development: low (0 to 0.4$)$; regular (0.4 to 0.6 ); moderate (0.6 to 0.8$)$; and high (0.8 to 1$)$. Accordingly, the closer the index is to 1 , the greater the development of the locality (Firjan, 2015a).

The municipality is considered a protagonist of local development due to its proximity to the population. Also, it is the subnational entity with the greatest capacity to create efficient solutions to problems at the municipal level. In fact, municipal managers have precise knowledge of the priorities of the municipality due to their proximity to the population, which consequently reduces inefficient spending (Biderman \& Arvate, 2004). Also, social demands of the population such as education, health, generation of employment and income (Araujo, 2000) are more visible at the municipal level.

In the context of the municipality being the protagonist of local development, Varela, Martins, and Corrar (2009) and Diniz, Macedo, and Corrar (2012) observed that socioeconomic development is associated with public expenditure, especially expenditure related to social factors and quality of life in the form of education and health services. The establishment of CF (1988) enforced the muncipality to assume new roles including access to revenues from intergovernmental transfers. Despite this, muncipilalities have not developed mechanisms that prioritize their role as articulator and protagonist of municipal development. On one hand, pressure to meet repressed local demands (basic urban infrastructure, public services and social policies) consume majority of municipal resources and capacity. On the other hand, the federal government left much to be desired in relation to the valorization of the municipality as a promoter of local socioeconomic development (Martins, Vaz, \& Caldas, 2010).

Until the end of 2000, municipal public administration in Brazil was marked with the misuse of public resources which culminated in high levels of corruption and debts related to the lack of fiscal responsibility of managers, lax legislation and lack of enforcement and control mechanisms at the municipal level (Klering, Kruel, \& Stranz, 2013; Oliveira, Peter, \& Meneses, 2010; Sousa et al., 2013).

In this context, several successful examples of planning and control in public management served as the basis for Brazil to debate, construct control mechanism of public expenditures and hold managers accountable for public resources under their care (Sousa et al., 2013).

Thus, the enactment of LC 101 (2000) imposed greater rigor on the planning and budget execution in Brazil, enforcing discipline in the management of public resources greater responsibility and 
transparency on the part of managers. LC 10 (2000) limited the expenditure and debts of public entities. It also sought to balance public revenues and expenditures and prioritized investments for the development and improvement of social indicators (Fioravante, Pinheiro, \& Vieira, 2006; Oliveira et al., 2010). LC 101 (2000) emerged from the need to impose limits on public managers, at various levels of the government, in order to generate smaller fiscal deficits and debts, among other benefits associated with responsible fiscal attitude (Fioravante et al., 2006).

In order to measure the quality of public management, evidenced through factors such as the control of expenditures and investments, and compliance with social rights in the constitution, several indicators were created to measure the performance of muncipalities as regards municipal public management (Sousa et al., 2013 ). IFGF aims to stimulate the culture of administrative responsibility through the generation and dissemination of indicators which enable municipal managers to make informed decisions regarding the allocation of public resources, as well as improve the social control of the fiscal management of municipalities (Firjan, 2015b).

The IFGF index was constructed based on municipal tax results - mandatory report on tax returns, revenue dates, expenses, assets and liabilities - made available annually by the National Treasury Secretariat (NTS) and the Financiers of Brazil database (Finbra). In addition, information is collected from national accounts and the Brazilian Institute of Geography and Statistics (BIGS). The index vary from 0 (worst situation) to 1 (best situation), and classifies municipal management into 4 categories of quality: A (Excellent, with results higher than 0.8); B (Good, between 0.6 and 0.8); C (In difficulty, between 0.4 and 0.6 ); and D (Critical, below 0.4 ).

With the decentralization of municipal revenues and functions after the CF (1988) law was passed, municipal fiscal management assumed new responsibilities in combating regional development disparities and complying with additional legal requirements of municipal managers (Cardoso, 2009). However, it should be pointed out that, despite the sharing of power, the decentralization of tax collection was not fully achieved as the Union increased its revenue in taxes not shared with federated entities. According to Bechara (2015), the expansion of the tax base occurred through the excessive establishment of so-called special contributions, in particular, social and intervention contributions in the economic domain. The contributions were originally conceived as parafiscal charges and were directed towards the collection of resources for specific purposes, in favor of a certain group of taxpayers.

This new scenario combined with the misuse of public resources anticipated the fiscal/financial strangulation of municipalities and made local demands difficult to meet. Not to mention, the public finance standards aimed at fiscal responsibility, such as the Fiscal Responsibility Law (LRF) which requires the public administration to formulate effective and efficient policies in services provided to the population (Marinho \& Jorge, 2015).

According to Moutinho (2016), a central point to consider when addressing the use of resources by the municipal public management is the scarcity of resources in most Brazilian municipalities, thus majority of the municipal resources are resources transferred from higher entities, making the manager practically the only person responsible for the allocation of these resources.

Thus, municipalities need to optimize the use of resources, which are limited, to achieve increasing levels of socioeconomic development. However, the efficient use of resources to promote development 
is a challenge, given the imbalances and particularities of the municipalities such as different demands, resources and priorities (Costa et al., 2015).

The literature and legislation on applied public finances have emphasized parameters related to the fulfillment of goals and legal limits for fiscal management as being responsible fiscal management, associated to the concepts of planning, control, transparency and accountability (Cruz \& Afonso, 2018).

According to Biderman and Arvate (2004), the main aim of public management is to use public resources so as to maximize the welfare of the society. The allocation of resources should be optimal since resources are limited. Thus, for Motta (2013), public administrators must meet the needs of population through the efficient use of available resources.

Thus, it can be inferred that the population desires efficient application of resources in services that improve quality of life. Thus, there is an immediate impact on the quality and scope of services coupled with urgency for demands to be met (Motta, 2013). As highlighted by Afonso, Romero-Barrutieta, and Monsalve (2013), public managers face serious difficulties in deciding where public resources should be applied in order to maximize the well-being of the population. In this context, efficient fiscal management emerges as a key indicator of decision-making in public expenditure.

According to Jorge and Cajazeira (2015), many managers argue that to balance public accounts imposed by LRF, social investments must be restricted which in turn hampers local development. Given the expansion of municipal administrative functions, managers face the dilemma of reconciling the objectives of LRF (to control and reduce public expenditures) with the expansion of expenditure predicted in the CF (1988). It should also be noted that the population is not only concerned with fiscal responsibility but also honest spending that promotes social benefits and development (Leite \& Peres, 2010).

\section{METHODOLOGICAL APPROACH}

In order to meet the objective of this study, we opted for panel data regression and Granger causality test. The methods are justified since they allow the causality between two variables of interest to be identified, stipulating whether X 'Granger-causes' $\mathrm{Y}$ and if past values of $\mathrm{X}$ predict the present value of Y.

Panel data analysis was utilized in this study. According to Hsiao (1986), a panel consists of the observation of a time series of data for a determined number of entities, called cross sections. In this study, the entities were 4,317 Brazilian municipalities that regularly reported IFGF data for the 2013 fiscal year, and IFDM data for the time series of 2006 to 2013. The definition of this period is compatible with the availability of the indicators by year - in the Firjan system - 2015 edition. The model estimated from the panel data of the study is presented in equation 1 :

$$
I F D M_{i t=\beta_{1} I F D M_{i t-1}+\beta_{2} I F D M_{i t-2}+\beta_{3} I F G F_{i t}+\beta_{4} I F G F_{i t-1}+\beta_{5} I F G F_{i t-2}+\varepsilon_{i t}}
$$

Where the dependent variable in Equation (1) refers to IFDM and the explanatory variable is lagged IFDM (dependent variable) and IFGF (level and lagged). Both variables are measured on a scale of 0 to 1 , where the closer to 1 , the better the fiscal management performance and municipal development. 
For this study, System-GMM developed by Arellano and Bover (1995) and Blundell and Bond (1998) was utilized. The dynamic nature of the panel is captured precisely by employing the lagged dependent variable as an explanatory variable since the explanatory variable is affected to some extent by the variable it should explain. In this case, $x=g(y)$ breaks the hypothesis of identification and generates $E[x e] \neq 0$ which in tend breaks the hypothesis of exogeneity of the variable or causes no correlation with the error terms of the regression model. In order to reduce the problems of endogeneity associated with the model, instrumental variables were used.

When explanatory variables are correlated with error terms, the concept is to replace the variables with other regressors. This method is known as instrumental variable method and the variables are called instruments. The instrumental variables, $\mathrm{z}$, would be auxiliary with the following properties: (i) $E[x z] \neq 0$ e (ii) $E[z e]=0$. Thus, if we take the portion of $\mathrm{x}$ that is related to $\mathrm{z}$, we will be able to identify an information set that will respect the hypothesis of identification $E[x e]=0$.

According to Wooldridge (2002), an instrumental variable must meet two requirements: it must not be correlated with the endogenous explanatory variables nor with the error term. That is, it should not present a similar problem as the substituted variable. Normally, the lags of the regression variables are used as instruments (Castro \& Yoshinaga, 2012).

An alternative is the use of GMM estimates. Arellano and Bond (1991) proposed a dynamic panel regression, where a first order differential equation is used, which eliminates fixed effects. However, for short panels, the instruments may be weak and the problem of endogeneity may still persist. Thus, Arellano and Bover (1995) and Blundell and Bond (1998) suggest the use of lagged first differences as instrumental variables for the level equation; and lagged variables for the first difference equation. This introduces the estimation method, also known as System-GMM.

It is important that one defines the criteria for the quantification and validation of the instruments. To avoid over-identification, it is recommended that the number of instruments be lower or equal to the number of groups investigated (Roodman, 2009). Thus, the Arellano and Bond (1991) test was employed for the first and second order autocorrelation due to the sensitivity of the dynamic panel to residual autocorrelation. To achieve a robust estimation, the null hypothesis of no first order autocorrelation must be rejected while the null hypothesis of no second order autocorrelation must be accepted.

Even though it is possible to consistently estimate the regression parameters between $\mathrm{x}$ and $\mathrm{y}$, the causal relationship between the variables is an important question that cannot be left unanswered. How can we assume that $\mathrm{y}=\mathrm{f}(\mathrm{x})$ and $\mathrm{x}=\mathrm{g}(\mathrm{y})$ or both situations occur simultaneously? Thus, the statistical relationship between two or more variables, irrespective of its strength, can never establish a causal relationship between the same; Kendall \& Stuart, 1961). In fact, convictions about any causal relationship must not be related to statistics, but should rather be based on established theory or common sense (Kendall \& Stuart, 1961).

The Granger causality test (1969) aims to overcome the limitations of using simple correlations between variables. This distinction is of fundamental importance, since a correlation, in itself, does not imply causality (cause and effect). Although the application of causality in time series models has been widely explored; its extension to panel data is a recent methodological approach (Holtz- 
Eakin, Newey, \& Rosen, 1988; Hurlin, 2005). This approach is based on an extended version of the technique elaborated by Granger and Huang (1997), which adapts the established concept of causality to panel data. Therefore, this procedure was adopted in the present study to test causality following the recommendation of Hurlin (2005).

The choice of this procedure is justified since the model is a heterogeneous panel model and presents a relatively short time series. The main advantage of using a causality test with panel data is the higher number of observations, increasing the degrees of freedom and efficiency of the estimated parameter since the power of the panel tests is remarkably greater than that obtained from time series test (Hurlin, 2005).

The Hurlin model (2005) tests the hypothesis of non-homogeneous causality from a variable $\mathrm{x}$ to a variable $y$ in a bivariate system. For the null hypothesis, it is assumed that there is no Granger causality relation from $\mathrm{x}$ to $\mathrm{y}$ for " $\mathrm{n}$ " individuals of the sample. However, its alternative hypothesis does not necessarily imply a causal relationship for all individuals in the panel, as in the case of the homogeneous model of Holtz-Eakin, Newey, and Rosen (1988). The test adopts an alternative heterogeneous specification in which 2 subgroups of individuals can coexist: a first subgroup of individuals for which there is a causal relationship from $\mathrm{x}$ to $\mathrm{y}$ and a second subgroup of individuals for which there is no causal relationship, the size and individuals of these 2 respective sets are unknown. The Hurlin test (2005) is formulated as follows:

$$
\begin{aligned}
& x_{i, t}=\alpha_{i}+\sum_{k=1}^{k} \gamma i^{(k)} x_{i, t-k}+\sum_{k=1}^{k} \beta i^{(k)} y_{i, t-k}+\varepsilon_{i t} \\
& y_{i, t}=\alpha_{i}+\sum_{k=1}^{k} \gamma i^{(k)} y_{i, t-k}+\sum_{k=1}^{k} \beta i^{(k)} x_{i, t-k}+\varepsilon_{i t}
\end{aligned}
$$

Equations (2) and (3) Xi,t are a measure of the quality of municipal fiscal management $i$ in year $t$, $Y i, t$ is a measure of the socioeconomic development of the municipality $i$ in year $\mathrm{t}$, ai are fixed effects that capture the individual heterogeneity of the municipalities, with $\mathrm{K} \in \mathbb{N}$ and $\beta i=\left(\beta i^{(1)}, \ldots, \beta i^{(\mathrm{K})}\right.$. The initial conditions $(\mathrm{yi},-\mathrm{K}, \ldots, \mathrm{yi}, 0)$ and $(\mathrm{xi},-\mathrm{K}, \ldots, \mathrm{xi}, 0)$ of the individual processes $Y i, t \mathrm{e} X i, t$ are the given and observable conditions with 1 and 2 identical lags $(K)$ for all units of the cross section of the panel, which is balanced.

Equation (2) postulates that current values of $\mathrm{X}$ are related to past values of $\mathrm{X}$ as well as lagged values of Y; Equation (3), on the other hand, postulates a similar behavior for the variable Y. Nothing prevents the variables $\mathrm{X}$ and $\mathrm{Y}$ from being represented in the form of growth rates, which, incidentally, has been always the rule in the literature since stationary variables in levels are almost not observed.

The method is combined with the F statistical test (Wald test) in order to verify if the coefficients of the lagged variables are jointly invalid. For example, if $\gamma 1=\ldots=\gamma \mathrm{i}=0$, then past values of $\mathrm{X}$ do not explain the current behavior of $Y$. If $\beta 1=\ldots=\beta i=0$ then past values of $Y$ do not explain the current behavior of $X$. Thus, there is unidirectional Granger causality from $Y$ to $X$ if not all $\beta$ i are equal to zero in (2), but all $\gamma \mathrm{i}$ are equal to zero in (3). Conversely, there will be unidirectional Granger causality from $X$ to $Y$ if all $\beta i$ are equal to zero in (2), but not all $\gamma$ i are equal to zero in (3). There may be bidirectional Granger causality between $\mathrm{X}$ and $\mathrm{Y}$ if not all $\beta \mathrm{i}$ are equal to zero and if not all $\gamma \mathrm{i}$ are 
equal to zero. Finally, there may be situations where no Granger causality exists between $\mathrm{X}$ and $\mathrm{Y}$, it only requires that all $\beta \mathrm{i}$ and $\gamma \mathrm{i}$ be equal to zero.

After estimating by the Granger method, 4 different hypotheses were defined and tested:

H1: lagged IFGF values help to explain the current value of IFDM, i.e., the ratio is unidirectional, or unicausal, from IFGF to IFDM;

H2: lagged values of IFDM help to explain the current value of IFGF, i.e., the ratio is unidirectional, or unicausal, from IFDM to IFGF;

H3: lagged IFGF values explain the current value of IFDM while lagged IFDM values explain the current value of IFGF, i.e., they are determined simultaneously;

H4: lagged IFGF values do not determine the current values of IFDM, and the lagged IFDM values do not determine current value of IFGF, i.e., the two time series are independent.

\section{ANALYSIS AND DISCUSSION OF RESULTS}

In order to study the behavior of the variables used in modeling the Brazilian municipal units in the period of 2006 to 2013, an exploratory data analysis (EDA) was used in relation to the measures of center, distribution and dispersion (Table 1).

\section{TABLE 1 DESCRIPTIVE STATISTICS, IFDM AND IFGF}

\begin{tabular}{|c|c|c|c|c|c|}
\hline Variables & Variation & Mean & Standard Deviation & Minimum & Maximum \\
\hline \multirow[t]{3}{*}{ IFDM } & Overall & 0.6228 & 0.1189 & 0.1592 & 0.9233 \\
\hline & Between & & 0.1107 & 0.2933 & 0.8890 \\
\hline & Within & & 0.0433 & 0.4128 & 0.7940 \\
\hline \multirow[t]{3}{*}{ IFGF } & Overall & 0.5058 & 0.1418 & 0.0428 & 0.9931 \\
\hline & Between & & 0.1159 & 0.1139 & 0.9204 \\
\hline & Within & & 0.0818 & 0.0874 & 0.8923 \\
\hline
\end{tabular}

Source: Elaborated by the authors

From the descriptive statistics of the IFDM and IFGF variables, in general, it is possible to observe that the indicators present values of high amplitude, as well as a wide dispersion of mean IFDM and IFGF. The variation between the IFDM and IFGF observations indicates that the municipalities are systematically different from each other and this variation is greater than the variation from one observation to another (within). 
It should be emphasized that the indexes are independent random variables and without perfect collinearity, since they are absolute values, fruit of the municipal conditions measured year by year ${ }^{1}$; allowing the use of panel. We also highlight the choice of using the indexes instead of the variables that compose them, since they guide management practices and public actions of the municipalities, going beyond an algebraic sense to symbolic, managerial and cultural role. As an aggravating factor, the indicators that compose the indexes have different weights due to discretionary reasons, which could be a possible source of bias when the original components are applied individually.

Table 2 shows the correlations between IFDM and IFGF indicators in level and lagged.

TABLE 2 CORRELATION BETWEEN IFDM AND IFGF INDICATORS

\begin{tabular}{|c|c|c|c|c|c|c|}
\hline & $\mathrm{IFDM}_{i t}$ & IFDM $_{i t-1}$ & $\mathrm{IFDM}_{i t-2}$ & $\mathrm{IFGF}_{i t}$ & $\mathrm{IFGF}_{i t-1}$ & $\mathrm{IFGF}_{i t-2}$ \\
\hline $\mathrm{IFDM}_{\mathrm{it}}$ & 1.0000 & & & & & \\
\hline $\mathrm{IFDM}_{\mathrm{it}-1}$ & 0.9551 & 1.0000 & & & & \\
\hline $\mathrm{IFDM}_{\mathrm{it}-2}$ & 0.9379 & 0.9563 & 1.0000 & & & \\
\hline $\mathrm{IFGF}_{i t}$ & 0.4232 & 0.4243 & 0.4176 & 1.0000 & & \\
\hline $\mathrm{IFGF}_{i t-1}$ & 0.4496 & 0.4425 & 0.4450 & 0.7195 & 1.0000 & \\
\hline $\mathrm{IFGF}_{i t-2}$ & 0.4507 & 0.4493 & 0.4438 & 0.6551 & 0.7391 & 1.0000 \\
\hline
\end{tabular}

Source: Elaborated by the authors.

It is possible to observe that the variables IFDM and IFGF apparently have a significant association, due to their high positive correlation indexes. IFGF presents a high correlation with IFDM, and its degree of association increases as the lag of IFGF, which seems to characterize some degree of temporal precedence. However, to confirm this precedence, the Granger causality test was applied. To perform the Granger causality test on the panel data, it is first necessary to analyze whether the series are non-stationary at level. According to Maddala and Wu (1999), for small samples, traditional unit root tests have little power against alternative hypotheses of stationarity. In addition, the use of panel data analysis reduces the power problem of unit root tests based on individual series, increasing the number of observations, combining time-series and cross-sectional dimensions. Table 3 presents the results of the unit root tests in panel data.

\footnotetext{
${ }^{1}$ More information on the methodology used for the construction of the indexes is available in Firjan (2017).
} 
TABLE 3 STATIONARITY TEST, PANEL DATA

$\begin{array}{cccccc}\text { Variable } & \text { Test } & \text { Lag } & \text { H0 } & \text { H1 } & P \text { value } \\ & \text { Levin-Lin-Chu } & 0 & \text { Unit root } & \text { Stationary } & 0.000 \\ \text { Harris-Tzavalis } & 0 & \text { Unit root } & \text { Stationary } & 0.000 \\ \text { IFDM } & \text { Breitung } & 0 & \text { Unit root } & \text { Stationary } & 0.000 \\ & \text { Im-Pesaran-Shin } & 0 & \text { Unit root } & \text { Stationary } & 0.000 \\ & \text { Fisher Type } & 0 & \text { Unit root } & \text { Stationary } & 0.000 \\ & \text { Levin-Lin-Chu } & 0 & \text { Unit root } & \text { Stationary } & 0.000 \\ & \text { Harris-Tzavalis } & 0 & \text { Unit root } & \text { Stationary } & 0.000 \\ & \text { Breitung } & 0 & \text { Unit root } & \text { Stationary } & 0.000 \\ & \text { Im-Pesaran-Shin } & 0 & \text { Unit root } & \text { Stationary } & 0.000 \\ & \text { Fisher Type } & 0 & \text { Unit root } & \text { Stationary } & 0.000\end{array}$

Source: Elaborated by the authors.

The unit root tests indicated that the IFDM and IFGF variables are stationary in level, that is, both are I (0). Thus, the regressions were estimated with the variables in level.

To analyze the relationship between fiscal management (IFGF) and municipal development (IFDM), we estimated the regression model in the System-GMM panel data (Table 4). The tests performed on the model reveal that it was significant as a whole and that the estimators reached the desired statistical properties. The Wald test rejected the null hypothesis of homoscedasticity and the Wooldridge test rejected the null hypothesis of no autocorrelation. Thus, robust standard errors were applied to correct the models. After, the Arellano and Bond test (1991) was employed, where the first-order autocorrelation was rejected but the null hypothesis of no second order autocorrelation was accepted, proving estimation consistency.

\section{TABLE 4 SYSTEM-GMM MODEL}

$\begin{array}{ccc}\text { Explanatory variable } & \text { IFDM } & \text { Standard errors } \\ \qquad \text { IFDM }_{i t-1} & 0.6933^{\star \star \star} & (0.0102) \\ \text { IFDM }_{i t-12} & 0.2372^{\star \star \star} & (0.0073) \\ \text { IFGF }_{i t} & -0.0586^{\star \star \star} & (0.0079) \\ \text { FGFF }_{i t-1} & 0.0588^{\star \star \star} & (0.0094)\end{array}$




$\begin{array}{ccc}\text { Explanatory variable } & \text { IFDM } & \text { Standard errors } \\ \qquad \text { FGF }_{i t-2} & 0.0358^{\star \star \star} & (0.0082) \\ \text { Constant } & 0.2603^{\star \star \star} & \text { No autocorrelation } \\ \text { Number of observations: } 25.902 & F(5)=13277.73 & \text { 1st order }=0.0000 \\ \text { Number of groups: } 4.317 & \text { Prob }>F=0.0000 & \text { 2nd order }=0.9707 \\ \text { Number of instruments: } 41 & & \end{array}$

Source: Elaborated by the authors.

Note: (i). Standard errors are reported in brackets; (ii) Significance level ${ }^{\star \star \star} p<0.01{ }^{\star *} p<0.05{ }^{\star} p<0.1$.

The regression results showed that all variables were statistically significant at $1 \%$. The lagged dependent variable was significant and presented a positive coefficient, which affirms its dynamic character, showing that socioeconomic indicators that measure the current developmental stage of a given municipality are influenced by their past values. The IFDM variable with one lag best explained the current values of IFDM. With two lags, a positive effect was presented, however its intensity was low.

The IFGF variable presented an antagonistic behavior in level and lagged municipal development. The negative behavior found in level can be justified by the fact that the effects of fiscal management are not necessarily immediate, although negative effects can be immediate. In the long run, the balance of public accounts due to limited expenditure imposed on the municipal public manager by LRF creates financial conditions for municipalities to provide adequate public services to the population. This fact is corroborated by Nascimento and Debus (2002) and Costa et al. (2015), who found that the balance of public accounts through limited expenditure imposed on the municipal manager by LRF, initially created a negative effect, however it was an indispensable approach to ensure that public management have sufficient funds, in the long term, for public services essential to the population.

This same coefficient had a positive effect on the two lags when the socioeconomic development of the municipality was evaluated, corroborating the thesis that good fiscal management provides better socioeconomic development indicators, as observed by G. A. Fialho and T. M. M. Fialho, (2015a, 2015b). All the lags in the present study are in agreement with the results observed by Costa et al. (2015), where the effect of good fiscal management is often not immediate and does not significantly modify socioeconomic development in a short period of time. Considering the lags, the positive effect of fiscal management on municipal development was evidenced, highlighting the importance of the efficient use of the public resource and they indicate that the indiscriminate use of resources and the generation of public deficit are not beneficial to development. For Hermann (2002), public debt, a burden on management, has a negative effect on future development. Thus, municipal fiscal management must value the efficient use of resources and budget balance.

The Granger causality test in panel data makes it possible to infer the causal relationship between two variables; however, this causality relates to the existence of a temporal precedence of one variable 
over the other, provided there is statistical significance. Causality is not defined in the sense that one variable determines the other, but rather that it precedes and assists in predicting the behavior of another variable of interest (Carneiro, 1997).

In order to verify the existence of a causal relationship between fiscal management and municipal socioeconomic development, Granger's causality between IFGF and IFDM for Brazilian municipalities from 2006 to 2013 (Table 5) was analyzed in panel data. Table 5 shows that the hypothesis, lagged 'IFGF does not Granger-cause IFDM', was accepted, because the chi-square value was higher than the value in the distribution table. Thus, it can be inferred that the lagged IFGF values do not contain useful information to predict changes in IFDM; that is, statistically, fiscal management does not precede municipal socioeconomic development. When the inverse hypothesis was evaluated, we found that 'IFDM does not Granger-cause IFGF', indicating that municipal development with a lag does not precede fiscal management.

\section{TABLE 5 CAUSALITY BETWEEN LAGGED IFDM AND IFGF}

\begin{tabular}{lcc} 
Granger causality (2006-2013) & & \\
Variable & Chi2 & - probability \\
\hline IFDM does not Granger-cause IFGF & 2.18 & 0.1396 \\
IFGF does not Granger-cause IFDM & 0.34 & 0.5623
\end{tabular}

Source: Elaborated by the authors.

Once more, the hypothesis 'IFGF does not Granger-cause IFDM' is accepted, indicating that fiscal management was not decisive to predict the behavior of municipal development indicators, although the System-GMM regression model shows an association between these variables. However, the hypothesis 'IFDM does not Granger-cause IFGF' is rejected for two lags, contrary to the initial expectations of this study and findings reported in the literature (Table 6).

\section{TABLE $6 \quad$ CAUSALITY BETWEEN IFDM AND IFGF (TWO LAGS)}

$\begin{array}{lcc}\begin{array}{l}\text { Granger causality (2006-2013) } \\ \text { Variable }\end{array} & \text { Chi2 } & \text { - probability } \\ \text { IFDM does not Granger-cause IFGF } & 114.57 & 0.0000 \\ \text { IFGF does not Granger-cause IFDM } & 2.64 & 0,2673\end{array}$

Source: Elaborated by the authors. 
It was found that the lagged IFDM values help explain the current value of IFGF, thus there is a unidirectional or unicausal relation from IFDM to IFGF, confirming H2. It can be stated that past values of IFDM contain useful information to predict changes in IFGF and the statistics confirm that socioeconomic development precedes fiscal management.

Since the Granger causality test is of temporal precedence, the number of lags is a determinant. Thus, as the effect of fiscal management on development does not occur immediately, the use of two lags may have been decisive for the non-causality relation to development. The number of lags was restricted by the use of a "short panel", with a small time window (2006 to 2013), not taking into account the assumptions of the model. Increasing the number of lags may lead to an increase in the magnitude of the variance of the estimated coefficients and results in inaccuracies.

The causality between socioeconomic development and fiscal management can be explained by the fact that municipalities with better socioeconomic conditions can present a better level of efficiency in public spending than those with lower capacity. For Costa et al. (2015), the higher the development of a municipality, the higher its capacity to generate revenue for the maintenance of a balanced management. Another hypothesis is that highly developed municipalities, in terms of education, employment and income, have a different demand for services and public resources. Moreover, the electoral preference of voters can change, making them fiscally conservative (Alesina, Perotti, Tavares, Obstfeld, \& Eichengreen, 1998; Brender \& Drazen, 2008; Drazen \& Eslava, 2010). In this regard, fiscally conservative voters tend to learn about the implications of public spending over time and, consequently, punish managers who are not fiscally conservative (Kwak, 2017), thus pushing public managers to practice good fiscal management.

In addition, we consider the association of transparency with better development indicators, as discussed by Bellver and Kaufmann (2005) and Ribeiro and Zuccolotto (2014), where greater transparency was found in municipalities with better indicators of development, as well as its association with smaller public deficits, as found by Alt and Lassen (2006). We also highlight the work of Grimmelikhuijsen and Welch (2012), where the influence of transparency on the quality of fiscal management was verified, a fact explained by the possibility of effective social control mechanisms, making informed society demand good public management from government leaders.

\section{FINAL CONSIDERATION}

The applied regression model indicates that good fiscal management is associated with better socioeconomic development indicators. However, when the scenario of balancing public accounts without harming public services is considered, the model shows no causal relationship between fiscal management and development, demonstrating that efficient fiscal management does not always indicate adequate use of public resources for development.

The non-rejection of the hypothesis of non-causality between fiscal management and development may indicate that when municipal budget is adjusted following the public finance standards for responsible fiscal management, the supply of goods and services can be limited in some municipalities, influencing the outcomes of social and development policies. However, it should be emphasized that the results of the municipalities tend to vary according to their size and demographic profiles which caused different impacts on the efficient use of public resources and local demands for services. In 
addition, managers are faced with limitations due to the constitutional laws that combine expenditures in areas such as health and education, and unequal demographic profile of the localities. These factors have distinct impacts on fiscal management and local development, in the short and medium term.

A unidirectional causal relationship between development and fiscal management was found, which does not corroborate with the popular inverse causal relationship found in the literature. The unidirectional relationship can be explained by the presence of fiscally conservative and active voters in more developed municipalities, who demand efficient and transparent fiscal management from public managers. Although the results confirm the hypothesis that development influences fiscal management, distinct results can be obtained if new variables are inserted into the model, thus opens numerous possibilities for future studies. For instance, the relation between fiscal management and effectiveness of public spending can be investigated, as regards social factors and quality of life, indicated by life expectancy, health and education policies. In relation to controlled differences among the municipalities, the components of fiscal management must be dismembered and/or other variables of control must be inserted, such as the level of transfer dependency. 


\section{REFERENCES}

Afonso, A., Romero-Barrutieta, A., \& Monsalve, E. (2013, March). Public sector efficiency: evidence for Latin America (ISEG Economics Working Paper). Washington, DC: Inter-American Development Bank.

Alesina, A., Perotti, R., Tavares, J., Obstfeld, M., \& Eichengreen, B. (1998). The political economy of fiscal adjustments. Brookings Papers on Economic Activity, 1, 197-266.

Alt, J. E., \& Lassen, D. D. (2006). Fiscal transparency, political parties, and debt in OECD countries. European Economic Review, 50(6), 1403-1439.

Araujo, T. B. (2000). Ensaios sobre o desenvolvimento brasileiro: heranças e urgências. Rio de Janeiro, RJ: Revan.

Arellano, M., \& Bond, S. (1991). Some tests of specification for panel data: Monte Carlo evidence and an application to employment equations. The Review of Economic Studies, 58(2), 277-297.

Arellano, M., \& Bover, O. (1995). Another look at the instrumental variable estimation of errorcomponents models. Journal of Econometrics, 68(1), 29-51.

Bechara, C. H. T., \& Carvalho, J. R. G. (2015). Federalismo e tributação: entre competição e cooperação. In M. A. M. Derzi, O. A. Batista, Júnior, \& A. M. Moreira (Orgs.), Estado federal e tributação: das origens á crise atual (Coleção Federalismo e Tributação, Vol. 1, pp. 35-54). Belo Horizonte, MG: Arraes.

Bellver, A., \& Kaufmann, D. (2005, September). Transparenting transparency: initial empirics and policy applications (World Bank Policy Research Working Paper). Washington, DC: World Bank.

Biderman, C., \& Arvate, P. R. (2004). Economia do setor público no Brasil (3a ed.). Rio de Janeiro, RJ: Elsevier.

Blundell, R., \& Bond, S. (1998). Initial conditions and moment restrictions in dynamic panel data models. Journal of Econometrics, 87(1), 115-143.

Brender, A., \& Drazen, A. (2008). How do budget deficits and economic growth affect reelection prospects? Evidence from a large panel of countries. The American Economic Review, 98(5), 2203-2220.
Bresser-Pereira, L. C. (2008). O modelo estrutural de gerência pública. Revista de Administração Pública, 42(2), 391-410.

Cardoso, J. C., Jr. (2009). Brasil em desenvolvimento: Estado, planejamento e políticas públicas. Brasília, DF: Instituto de Pesquisa Econômica Aplicada.

Carneiro, F. G. (1997). A metodologia dos testes de causalidade em economia (Série Textos Didáticos n. 20). Brasília, DF: Universidade de Brasília.

Castro, F. H. F., Junior, \& Yoshinaga, C. E. (2012). Coassimetria, cocurtose e as taxas de retorno das ações: uma análise com dados em painel. Revista de Administração Mackenzie, 13, 110-144.

Constituição da República Federativa do Brasil, de 5 de outubro de 1988. (1988). Brasília, DF.

Costa, C. C. M., Ferreira, M. A. M., Braga, M. J., \& Abrantes, L. A. (2015). Fatores associados à eficiência na alocação de recursos públicos à luz do modelo de regressão quantílica. Revista de Administração Pública, 49(5), 1319-1347.

Cruz, C. F., \& Afonso, L. E. (2018). Gestão fiscal e pilares da Lei de Responsabilidade Fiscal: evidências em grandes municípios. Revista de Administração Pública, 52(1), 126-148.

Diniz, J. A., Macedo, M. A. S., \& Corrar, L. J. (2012). Mensuração da eficiência financeira municipal no Brasil e sua relação com os gastos nas funções de governo. Gestão \& Regionalidade, 28(83), 5-20.

Drazen, A., \& Eslava, M. (2010). Electoral manipulation via voter-friendly spending: theory and evidence. Journal of Development Economics, 92(1), 39-52.

Easterly, W., \& Rebelo, S. (1993). Fiscal policy and economic growth. Journal of Monetary Economics, 32(3), 417-458.

Federação das Indústrias do Estado do Rio de Janeiro. (2015a). Indice Firjan de Desenvolvimento Municipal. Rio de Janeiro, RJ: Author.

Federação das Indústrias do Estado do Rio de Janeiro. (2015b). Índice Firjan de Gestão Fiscal. Rio de Janeiro, RJ: Author.

Federação das Indústrias do Estado do Rio de Janeiro. (2017). Metodologia. Rio de Janeiro, RJ: Author. Retrieved from https://www.firjan.com.br/data/ 
files/E2/82/21/A0/9AF3E5107210A3E5A8A809C2/ Anexo\%20Metodol\%C3\%B3gico\%20IFGF\%20 2017.pdf

Fialho, G. A. L., \& Fialho, T. M. M. (2015a). Associação entre os indicadores de qualidade da gestão pública municipal e indicadores de desenvolvimento dos municípios brasileiros. Gestão Pública: Práticas e Desafios, 8(2), 1-15.

Fialho, G. A. L., \& Fialho, T. M. M. (2015b). Relação entre indicadores de qualidade da gestão pública e de desenvolvimento dos municípios brasileiros. Cadernos Gestão Pública e Cidadania, 20(67), 277295.

Fioravante, D. G., Pinheiro, M. M. S., \& Vieira, R. S. (2006, outubro). Lei de Responsabilidade Fiscal e finanças públicas municipais: impactos sobre despesas com pessoal e endividamento (Texto para Discussão n. 1223). Brasília, DF: Instituto de Pesquisa Econômica Aplicada.

Granger, C. W. J. (1969). Investigating causal relations by econometric models and cross-spectral methods. Econometrica: Journal of the Econometric Society, 37(3), 424-438.

Granger, C. W. J., \& Huang, L. L. (1997). Evaluation of panel data models: some suggestions from time series (Mimeographed). San Diego, CA: University of California, San Diego.

Grimmelikhuijsen, S. G., \& Welch, E. W. (2012). Developing and testing a theoretical framework for computer-mediated transparency of local governments. Public Administration Review, 72(4), 562-571.

Hermann, J. (2002). A macroeconomia da dívida pública: notas sobre o debate teórico e a experiência brasileira recente (1999-2002). Cadernos Adenauer, 3(4), 41-70.

Holtz-Eakin, D., Newey, W., \& Rosen, H. S. (1988). Estimating vector autoregressions with panel data. Econometrica: Journal of the Econometric Society, 56(6), 1371-1395.

Hsiao, C. (1986). Analysis of panel data. Cambridge, England: Cambridge University Press.

Hurlin, C. (2005). Testing Granger causality in heterogeneous panel data models. Revue Économique, 56(3), 799-809.
Jorge, M. A., \& Cajazeira, A. P. G. B. (2015). Responsabilidade fiscal e desenvolvimento municipal: uma análise dos municípios sergipanos no período 2007/2010. Pesquisa \& Debate, 26(1), 124-149.

Kendall, M. G., \& Stuart, A. (1961). The advanced theory of statistics. London, England: Griffin.

Klering, L. R., Kruel, A. J., \& Stranz, E. (2013). Os pequenos municípios do Brasil: uma análise a partir de índices de gestão. Análise - Revista de Administração da PUCRS, 23(1), 31-44.

Kneller, R., Bleaney, M. F., \& Gemmell, N. (1999). Fiscal policy and growth: evidence from OECD countries. Journal of Public Economics, 74(2), 171190 .

Kwak, S. (2017). Cyclical asymmetry in State fiscal policy: is it biased toward big or small government? The American Review of Public Administration, 47(8), 962-976.

Lei n. 9.496, de 11 de setembro de 1997. (1997). Estabelece critérios para a consolidação, a assunção e o refinanciamento, pela União, da dívida pública mobiliária e outras que especifica, de responsabilidade dos Estados e do Distrito Federal. Brasília, DF.

Lei Complementar n. 101, de 4 de maio de 2000. (2000). Estabelece normas de finanças públicas voltadas para a responsabilidade na gestão fiscal e dá outras providências. Brasília, DF.

Leite, C. K. S., \& Peres, Ú. D. (2010). Lei de Responsabilidade Fiscal, federalismo e políticas públicas: um balanço crítico dos impactos da LRF nos municípios brasileiros. In A. S. Cunha, B. A. Medeiros, \& L. M. C., Aquino (Orgs.), Estado, instituições e democracia: república (Vol. 1, pp. 213248). Brasília, DF: Instituto de Pesquisa Econômica Aplicada.

Maddala, G. S., \& Wu, S. (1999). A comparative study of unit root tests with panel data and a new simple test. Oxford Bulletin of Economics and statistics, 61(Suppl. 1), 631-652.

Marinho, A. P. S., \& Jorge, M. A. (2015). O planejamento local é mais eficiente? Uma análise de 14 municípios sergipanos de pequeno porte. Nova Economia, 25, 123-142. 
Martins, R. A., Vaz, J. C., \& Caldas, E. L. (2010). A gestão do desenvolvimento local no Brasil: (des) articulação de atores, instrumentos e território. Revista de Administração Pública, 44(3), 559-590.

Massardi, W. O., \& Abrantes, L. A. (2016). Dependência dos municípios de Minas Gerais em relação ao FPM. Revista de Gestão, Finanças e Contabilidade, 1(6), 173-187.

Motta, P. R. M. (2013). O estado da arte da gestão pública. Revista de Administração de Empresas, 53, 82-90.

Moutinho, J. A. (2016). Transferências voluntárias da União para municípios brasileiros: mapeamento do cenário nacional. Revista de Administração Pública, 50(1), 151-166.

Nascimento, E. R., \& Debus, I. (2002). Lei Complementar no. 101/2000: entendendo a lei de responsabilidade fiscal. Brasília, DF: Secretaria do Tesouro Nacional.

Oliveira, F. H., Peter, M. G. A., \& Meneses, A. F. (2010, julho). Lei de Responsabilidade Fiscal: implicações nos indicadores sociais municipais. In Anais do 10o Congresso USP de Controladoria e Contabilidade. São Paulo, SP.

Ribeiro, C. P. P., \& Zuccolotto, R. (2014). A face oculta do Leviatã: transparência fiscal nos municípios brasileiros e suas determinantes socioeconômicas e fiscais. Enfoque: Reflexão Contábil, 33(1), 37-52.

Roodman, D. (2009). How to do xtabond2: an introduction to difference and system GMM in Stata. Stata Journal, 9(1), 86-136.

Scarpin, J. E., \& Slomski, V. (2007). Estudo dos fatores condicionantes do índice de desenvolvimento humano nos municípios do Estado do Paraná: instrumento de controladoria para a tomada de decisões na gestão governamental. Revista de Administração Pública, 41(5), 909-933.

Sen, A. K., Motta, L. T., \& Mendes, R. D. (2000). Desenvolvimento como liberdade. São Paulo, SP: Companhia das Letras.

Sousa, P. F. B., Lima, A. O., Nascimento, C. P. S., Peter, M. G. A., Machado, M. V. V., \& Gomes, A. O. (2013). Desenvolvimento municipal e cumprimento da Lei de Responsabilidade Fiscal: uma análise dos municípios brasileiros utilizando dados em painel. Revista Evidenciação Contábil \& Finanças, 1(1), 58-70.

Varela, P. S., Martins, G. A., \& Corrar, L. J. (2009). Perfil dos gastos públicos versus perfil econômicosocial dos municípios paulistas. Revista de Contabilidade e Organizações, 3(5), 80-97.

Wooldridge, J. M. (2002). Econometric analysis of cross section and panel data. Cambridge, MA: The MIT Press. 


\section{João Paulo de Oliveira Louzano}

https://orcid.org/0000-0002-2920-8003

$\mathrm{PhD}$ candidate, Administration, Federal University of Viçosa; Professor, Department of Accounting Sciences, Federal University of Jequitinhonha and Mucuri Valleys. E-mail: jplouzano@gmail.com

\section{Luiz Antonio Abrantes}

https://orcid.org/0000-0002-4460-125X

$\mathrm{PhD}$, Administration, Federal University of Lavras; Professor, Department of Administration and Accounting, Federal University of Viçosa. E-mail: abrantes@ufv.br

\section{Marco Aurélio Marques Ferreira}

ID

https://orcid.org/0000-0002-9538-1699

Post Doctorate, Public Administration, Rutgers University; PhD, Applied Economics, Federal University of Viçosa; Professor, Department of Administration and Accounting, Federal University of Viçosa.

E-mail: marcoufv1@gmail.com

\section{Robson Zuccolotto}

https://orcid.org/0000-0002-2629-5586

Post Doctorate, Public and Government Administration, Fundação Getúlio Vargas; PhD, Controllership and Accounting, University of São Paulo; Professor, Center for Legal and Economic Sciences, Federal University of Espírito Santo. E-mail: robsonzuccolotto@gmail.com 